\title{
EARLY DEVELOPMENT, SURVIVAL AND GROWTH RATES OF THE GIANT CLAM TRIDACNA CROCEA (BIVALVIA: TRIDACNIDAE)
}

\author{
Miguel Mies*, Felipe Braga, Marcello Santos Scozzafave, \\ Daniel Eduardo Lavanholi de Lemos and Paulo Yukio Gomes Sumida \\ Instituto Oceanográfico da Universidade de São Paulo \\ (Praça do Oceanográfico, 191, 05508-120 São Paulo, SP, Brasil) \\ *Corresponding author: miguel.mies@usp.br
}

\begin{abstract}
A B S T R A C T
Tridacnid clams are conspicuous inhabitants of Indo-Pacific coral reefs and are traded and cultivated for the aquarium and food industries. In the present study, daily growth rates of larvae of the giant clam Tridacna crocea were determined in the laboratory during the first week of life. Adults were induced to spawn via intra-gonadal serotonin injection through the byssal orifice. After spawning oocytes were collected, fertilized and kept in $3 \mathrm{~L}$ glass beakers and raceways treated with antibiotics to avoid culture contamination. Larvae were fed twice with the microalga Isochrysis galbana and zooxanthellae were also offered twice during the veliger stage (days 4 and 6). Larval length was measured using a digitizing tablet coupled to a microcomputer. Larval mortality was exponential during the first 48 hours of life declining significantly afterwards. Mean growth rate was $11.3 \mu \mathrm{m}$ day-1, increasing after addition of symbionts to $18.0 \mu \mathrm{m}$ day-1. Survival increased to ca. $75 \%$ after the addition of zooxanthellae. The results describe the growth curve for T. crocea larvae and suggest that the acquisition of symbionts by larvae may be useful for larval growth and survival even before larvae have attained metamorphosis.
\end{abstract}

\section{RESUMO}

Bivalves tridacnídeos são habitantes conspícuos dos recifes da região do Indo-Pacífico e são cultivados e comercializados para os mercados alimentício e aquarista. No estudo apresentado foram determinadas as taxas de crescimento diário durante a primeira semana de vida da larva do bivalve ornamental Tridacna crocea. As matrizes foram induzidas à desova por meio de uma injeção intragonadal de serotonina realizada através do orifício bissal. Após desova, ovócitos foram coletados, fertilizados e mantidos em béqueres de vidro e tanques de fluxo contínuo tratados com antibióticos para evitar contaminação. Larvas foram alimentadas em duas ocasiões com a microalga Isochrysis galbana e zooxantelas foram oferecidas também por duas vezes. O comprimento larval foi medido através de mesa digitalizadora conectada em um microcomputador. A mortalidade larval foi exponencial durante as primeiras 48 horas de vida, diminuindo em seguida. A taxa média de crescimento foi de $11,3 \mu \mathrm{m}$ dia-1, aumentando para $18,0 \mu \mathrm{m}$ dia-1 após a adição de simbiontes. A sobrevivência aumentou para $75 \%$ após a adição de zooxantelas. Os resultados apresentam a curva de crescimento para a larva de $T$. crocea e sugerem que a aquisição de simbiontes pela larva pode ser importante para o crescimento larval e sobrevivência mesmo antes delas completarem a metamorfose.

Descriptors: Tridacnidae, Ontogenesis, Zooxanthellae, Early growth, Symbiosis, Culture.

Descritores: Tridacnidae, Ontogênese, Zooxantelas, Crescimento Larval, Simbiose, Cultura.

\section{INTRODUCTION}

In the past two decades much attention has been drawn to the cultivation of giant clams for both the food and aquarium trade markets (ELLIS, 2000; LEUNG et al., 1993; DELBEEK; SPRUNG, 1997; KNOP, 2009). The mantle of giant clams is desired by aquarium hobbyists for the fantastic coloration and patterns they possess, while restaurants around Asia take it as a delicacy. Despite the interest, culturing tridacnids is rather difficult, with very low survival rates through the larval stages. The first obstacle when it comes to culturing is performing successful induced spawning. Induction methods employed can be dangerous and commonly kill part of the broodstock (KNOP, 1996), e.g. by the misplacement of hormone injections. Secondly, to obtain ripe eggs requires large specimens, given tridacnids are protandrous simultaneous hermaphrodites (NORTON; JONES, 1992; NASH et al., 1988). The third and probably hardest difficulty to overcome is to successfully 
complete the larval ontogenetic cycle. After fertilization a succession of short larval stages occurs, during which critical activities such as obtaining food and symbionts must happen within a few days, and mortality is high (ELLIS, 1998; FITT et al., 1984; KNOP, 1996).

The ontogeny of giant clams (Tridacna spp., Hippopus spp.) is similar to that of any other bivalve species, going through trochophore, veliger and pediveliger stages and then completing metamorphosis. The greatest difference resides in the fact that tridacnids are zooxanthellate, having an obligatory symbiotic relationship with the dinoflagellate Symbiodinium microadriaticum (YONGE, 1936). The transmission of the symbiont does not take place vertically, meaning it must be acquired by the clam larva when filter feeding in the water column (FITT; TRENCH, 1981). Recent discussion suggests that tridacnid larvae may benefit from the early acquistion of zooxanthellae (HIROSE et al., 2006; ISHIKURA et al., 1999), while past documentations declare that clams do not make use of their symbiotic relationship until after metamorphosis (FITT et al., 1984; FITT et al., 1986; YONGE, 1936).

Little is known about larval growth of giant clams, especially during the early life stages. Available data present only scattered growth measurements and only on a few species, mainly Tridacna gigas. Daily larval growth has not been reported and only a few studies have estimated the growth of tridacnid larvae (JAMESON, 1976; GWYTHER; MUNRO, 1981; HART et al., 1998). Additionally, some of those studies performed growth measurements despite the complete absence of zooxanthellae in the culture water throughout the larval cycle (GWYTHER; MUNRO, 1981).

The objective of the present study is to estimate the daily growth and survival rates of Tridacna crocea during the first week of life. Determination of daily survival and growth allows one to infer the viability of the eggs spawned, since poor vitellogenesis may produce oocytes that are weaker and less likely to succeed (GABBOTT, 1975). Additionally, daily larval growth may be correlated with the quality of the symbiont strain added (KLUMPP; GRIFFITHS, 1994), given the fact that different zooxanthellae strains may reflect differently on growth (FITT et al., 1986; MINGOA-LICUANAN, 2000).

The better comprehension of the larval growth and survival of giant clams is essential for culture evaluation and elaboration of protocols and practices. As to the effect of zooxanthellae on larval growth, determining daily growth could provide information that may corroborate or lead to the rejection of the hypothesis that growth may increase non-linearly after the uptake of zooxanthellae.
The species Tridacna crocea was chosen for the study mainly because it is the least studied of the giant clams, since, for restocking purposes more attention is given to larger and faster-growing clams such as T. gigas, T. derasa and Hippopus hippopus. Additionally, $T$. crocea is the smallest among giant clams, therefore being the easiest to handle in a laboratory. Further comprehension of the growth, survival and symbiosis of $T$. crocea could benefit the understanding of its ontogenesis, ecology and role in marine ecosystems, as well as of its culture and conservation.

\section{Material and Methods}

Tridacna crocea embryos and larvae were obtained from a small broodstock of individuals that were purchased from a vietnamese aquaculture facility. Adults were maintained in a recirculating system under constant temperature (ca. $26.5^{\circ} \mathrm{C}$ ) and physical-chemical parameters. The equipment used in the stabilizing of the parameters consisted of a $3 / 4 \mathrm{HP}$ chiller, a $300 \mathrm{~W}$ heater, a protein skimmer and a calcium reactor. The size of the adults ranged from 8 to $13 \mathrm{~cm}$ in length and none had been induced to spawn before the present study. Larval cultures were connected to the recirculating system, in two different types of vessel: six $3 \mathrm{~L}$ glass beakers and four $24 \mathrm{~L}$ plastic raceways. Artificial illumination was provided by $150 \mathrm{~W}$ metal halide lamps (photoperiod 10L:14D). The physical-chemical parameters of the water utilized in the larviculture were maintained stable throughout the experiment (Table 1).

Table 1. Physical-chemical parameters of the water used during the acclimation, spawning and larval culture of Tridacna crocea.

\begin{tabular}{|c|c|c|c|}
\hline Parameter & Range & Unit & Reference \\
\hline Temperature & $26.5-27.5$ & ${ }^{\circ} \mathrm{C}$ & Knop (1996) \\
\hline Specific gravity & 1025 & $\mathrm{~kg} \mathrm{~m}^{-3}$ & $\begin{array}{l}\text { Fatherree } \\
(2006)\end{array}$ \\
\hline $\mathrm{pH}$ & $8.3-8.4$ & - & Ellis (1998) \\
\hline $\begin{array}{l}\text { Carbonate } \\
\text { hardness }\end{array}$ & $8.0-9.0$ & $\mathrm{dKH}$ & Knop (1996) \\
\hline Calcium $\left(\mathrm{Ca}^{2+}\right)$ & $440-450$ & $\mathrm{mg} \mathrm{L}^{-1}$ & Knop (1996) \\
\hline $\begin{array}{l}\text { Magnesium } \\
\left(\mathrm{Mg}^{2+}\right)\end{array}$ & $1100-1200$ & $\mathrm{mg} \mathrm{L}^{-1}$ & $\begin{array}{l}\text { Culkin; Cox } \\
\text { (1966) }\end{array}$ \\
\hline $\begin{array}{l}\text { Ammonium } \\
\left(\mathrm{NH}_{4}{ }^{+}\right)\end{array}$ & 0.05 & $\mathrm{mg} \mathrm{L}^{-1}$ & $\begin{array}{l}\text { Fatherree } \\
(2006)\end{array}$ \\
\hline Nitrate $\left(\mathrm{NO}_{3}^{-}\right)$ & $1.0-1.5$ & $\mathrm{mg} \mathrm{L}^{-1}$ & $\begin{array}{l}\text { Fatherree } \\
\text { (2006) }\end{array}$ \\
\hline Nitrite $\left(\mathrm{NO}_{2}^{-}\right)$ & 0 & $\mathrm{mg} \mathrm{L}^{-1}$ & $\begin{array}{l}\text { Fatherree } \\
\text { (2006) }\end{array}$ \\
\hline $\begin{array}{l}\text { Phosphate } \\
\left(\mathrm{PO}_{4}{ }^{3-}\right)\end{array}$ & $<0.01$ & $\mathrm{mg} \mathrm{L}^{-1}$ & $\begin{array}{l}\text { Fatherree } \\
\text { (2006) }\end{array}$ \\
\hline
\end{tabular}

Six adult clams were induced to spawn by the injection of $1 \mathrm{~mL}$ of $1 \mathrm{~g} \mathrm{~L}^{-1}$ serotonin (5hydroxytryptamine, creatinine sulfate complex - 
Sigma Aldrich) solution in the gonads. Injection was performed via byssal orifice (MIES et al., 2011). Sperm was collected after spawning and oocytes after gamete reversion. Each clam was allowed to undergo contractions until it became utterly spent. Gametes were then mixed in glass beakers and plastic raceways in a 1:200 sperm:oocyte ratio by volume in order to attain fertilization and to prevent polyspermy (ELLIS, 1998).

Cultures were maintained under gentle aeration for 5 days starting 2 hours post-fertilization. During this period, $50 \%$ of the water was changed every 12 hours in the first day and every 24 hours afterwards. The stocking density of veligers in beakers was kept around 30 larvae $\mathrm{mL}^{-1}$ and in raceways at 10 larvae $\mathrm{mL}^{-1}$. On the fifth day after fertilization all veligers in the beakers were transferred to the $24 \mathrm{~L}$ plastic raceways and kept at 5 larvae $\mathrm{mL}^{-1}$. Feeding began on day three (HESLINGA et al., 1984; FATHERREE, 2006) and was tasked again on the fifth day. Five micrometer cells of Isochrysis galbana (tahitian T-iso strain) at a concentration of approximately $5 \times 10^{4}$ cells $\mathrm{mL}^{-1}$ was the food of choice for this study. The antibiotic cephalosporin (4 ppm) was added every 24 hours (FITT et al., 1992). The symbiotic dinoflagellates of the species Symbiodinium microadriaticum were retrieved from a small piece of the mantle of an adult conspecific after blending in seawater $\left(27^{\circ} \mathrm{C}, 1.025 \mathrm{~kg} \mathrm{~m}^{-3}\right)$ and filtering in a $40 \mu \mathrm{m}$ mesh to remove unwanted tissues and debris. The same procedure was performed with the soft coral Capnella imbricata (Anthozoa: Alcyonacea). Both zooxanthellae-rich solutions were mixed together and then added to the beakers and raceways on days 4 and 6 (ELLIS, 1998).

Cultures were homogenized and samples were collected daily with a Pasteur pipette. Thirty individuals (3 from each beaker/raceway) were transferred to Petri dishes and measured daily under a Leica DMLS stereomicroscope coupled to a Nikon Coolpix 995 camera and a Summasketch III digitizing tablet (Summagraphics, software Zoopbiom version 2.2). A segmented linear regression was applied to the five samples of the veliger stage, considering two groups: before and after the addition of zooxanthellae. Statistical difference was considered at $p<0.05$.

\section{RESULTS}

Sperm release always preceded egg release and the mean time for the first sperm release was 49.1 \pm 26.1 seconds after serotonin injection. After sperm emission, mature clams switched to the spawning of oocytes, which occurred in $15.0 \pm 7.7$ minutes. Germinal vesicle breakdown occurred and micropyles were evident 1 minute after oocyte release. Egg cleavage percentage was $86.2 \%$ and no substantial event of polyspermy was observed. Broodstock mortality was zero.

Aposymbiotic larvae hatched 11 hours after fertilization and developed into free-swimming ciliated trochophores. All larvae were veligers 30 hours post-fertilization. The first pediveliger was observed on the eighth day and by the twelfth day all living clams had become pediveligers. At the end of each day, extremely small red blotches of bacteria were spotted and those disappeared hours after the addition of the antibiotic cephalosporin. The microalga Isochrysis galbana was added on days 3 and 5 giving the water a light tan coloration. Over $94 \%$ of the larvae ingested the microalgae within 3 hours. Zooxanthellae offered to veligers presented intense motility with ca. $86 \%$ assimilation after 3 hours.

Mortality was high in the first 24 hours at trochophore stage (ca. 75\%), declining with time to only ca. $25 \%$ on the fifth day. Daily mortality also declined steadily with time, during the first 24 hours mortality reached its peak at $74.1 \%$, while in the next day it dropped to $56.5 \%$. From hour 48 to 72 , only about a third of the veligers perished, declining further in the next day to $27.5 \%$ (Table 2 , Fig. 1).

Embryos of Tridacna crocea had a mean length of $92.3 \pm 5.4 \mu \mathrm{m}$ and 16 hours post-fertilization, at trochophore stage, had already experienced a longitudinal growth exceeding $10 \mu \mathrm{m}$, about $10 \%$ of their original size. At a lifetime of less than two days, the early veligers had thin, recently formed calcareous shells (Fig. 4) that contributed to grow both in length and width. At this stage, individuals had already grown over a third beyond their embryonic size. Growth rate declined thereafter and at 4 days old veligers nearly halted. At that point larvae swam actively and started filtering larger particles such as the $40 \mu \mathrm{m}$ Symbiodinium microadriaticum cells added. Growth rate rose again on the days following the addition of symbionts (Fig. 2) but then decreased again and on the final day (hour 144) of the experiment the larvae had a mean shell length of $173.6 \pm 7.1 \mu \mathrm{m}$. On that same day symbionts were once again added, but growth and development were not assessed this time. These data demonstrate that $T$. crocea veliger larvae double their size in the first week.

The statistical analysis sought to observe any different growth tendencies related to zooxanthellae influence. It consisted of partitioning the independent variable into two different groups (pre and post zooxanthellae addition), adjusting a line segment to each group. After running the model, the distinct groups were evaluated as significantly different with $p$ $<0.001$ (Fig. 3). 
Table 2. Early growth, mortality and morphometrics of the first week of life of Tridacna crocea in laboratory. Thirty individuals were counted each day and daily mortality is given per beaker.

\begin{tabular}{cccccc}
\hline \hline $\begin{array}{c}\text { Time } \\
\text { (post-fertilization) }\end{array}$ & Stage & Size $(\mu \mathrm{m})$ & $\begin{array}{c}\text { Growth rate } \\
\left(\mu \mathrm{m} \mathrm{d}^{-1}\right)\end{array}$ & $\begin{array}{c}\text { Daily growth } \\
(\%)\end{array}$ & $\begin{array}{c}\text { Daily mortality } \\
(\%)\end{array}$ \\
\hline $0 \mathrm{~h}$ & embryo & $92.3 \pm 5.4$ & - & - & - \\
$24 \mathrm{~h}$ & trochophore & $104.2 \pm 6.6$ & 11.9 & 12 & $74.1 \pm 6,9$ \\
$48 \mathrm{~h}^{\mathrm{a}}$ & veliger & $124.0 \pm 3.7$ & 19.8 & 19 & $56.5 \pm 5,0$ \\
$72 \mathrm{~h}^{\mathrm{b}}$ & veliger & $134.4 \pm 4.9$ & 10.4 & 8 & $35.5 \pm 5,6$ \\
$96 \mathrm{~h}^{\mathrm{a}}$ & veliger & $137.6 \pm 5.5$ & 3.2 & 2 & $\mathrm{n} / \mathrm{a}$ \\
$120 \mathrm{~h}^{\mathrm{b}}$ & veliger & $159.7 \pm 7.2$ & 22.1 & 13 & $\mathrm{n} / \mathrm{a}$ \\
$144 \mathrm{~h}^{\mathrm{a}}$ & veliger & $173.6 \pm 7.1$ & 13.9 & 8 & \\
\hline
\end{tabular}

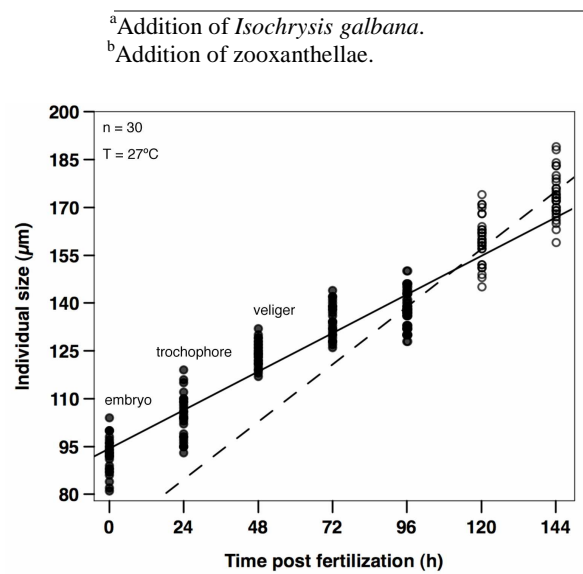

- before addition of zooxanthellae: $f=0.502778 X+94.4067 r=0.93$ after addition of zooxanthellae: $f=0.750694 X+66.9167 \quad r=0.91$

Fig. 1. Cumulative mortality of the reared larvae of Tridacna crocea during embryonic development and larval stages of trochophore and veliger.

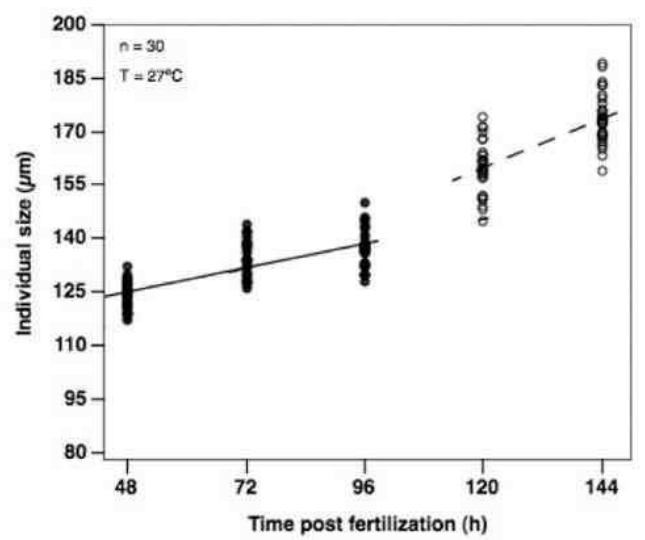

Fig. 2. Individual size of Tridacna crocea during the first week of life. Continuous lines mark growth tendency without zooxanthellae and non-continuous lines mark growth tendency with zooxanthellae.

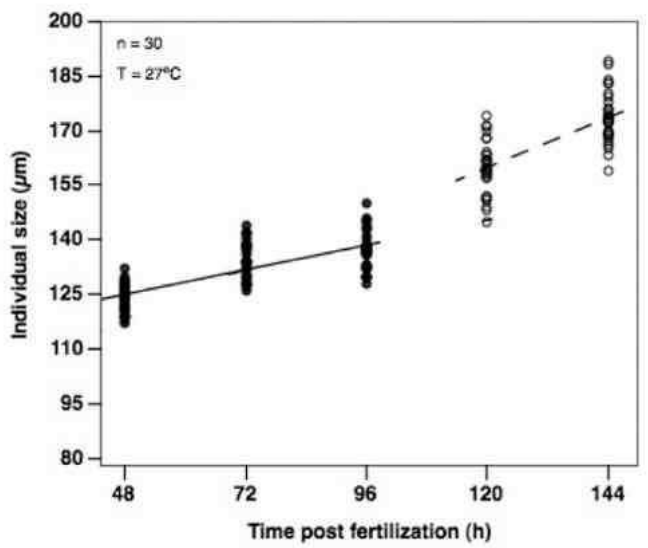

Fig. 3. Model of segmented linear regression adjusted on the growth of veliger larvae of Tridacna crocea. Growth $=$ $118,500+6,767 \mathrm{~T}+7,100 \mathrm{D}+7,100 \mathrm{P} ; \mathrm{T}=[1-5]$ for $[48-144 \mathrm{~h}]$; $\mathrm{D}=0$ before zooxanthellae addition and $\mathrm{D}=1$ after zooxanthellae addition; $\mathrm{P}=0$ before zooxanthellae addition, $\mathrm{P}=1$ at $120 \mathrm{~h}$ and $\mathrm{P}=2$ at $144 \mathrm{~h}$. Obtained value of significance of $p<0.001$.

\section{Discussion}

The inducing method performed in this study differed from the traditional one reported in spawning giant clams, when the hormone injection is applied in the mantle cavity (BRALEY, 1985; GIBBONS; CASTAGNA, 1984; KNOP, 2009). Other bivalve spawning induction methods include the addition of macerated gonad solution to the water, thermal stress and hydrogen peroxide injection (BECKVAR, 1981; FITT; TRENCH, 1981). The serotonin injection through the byssal orifice proved to be an effective inducing method. All clams spawned within 90 seconds of the injection and broodstock mortality was nil, differently from reports of inducing through heat stress and serotonin injection in the mantle cavity (ELLIS, 1998). The advantage of injecting through the byssal orifice is that there are no vital organs in 


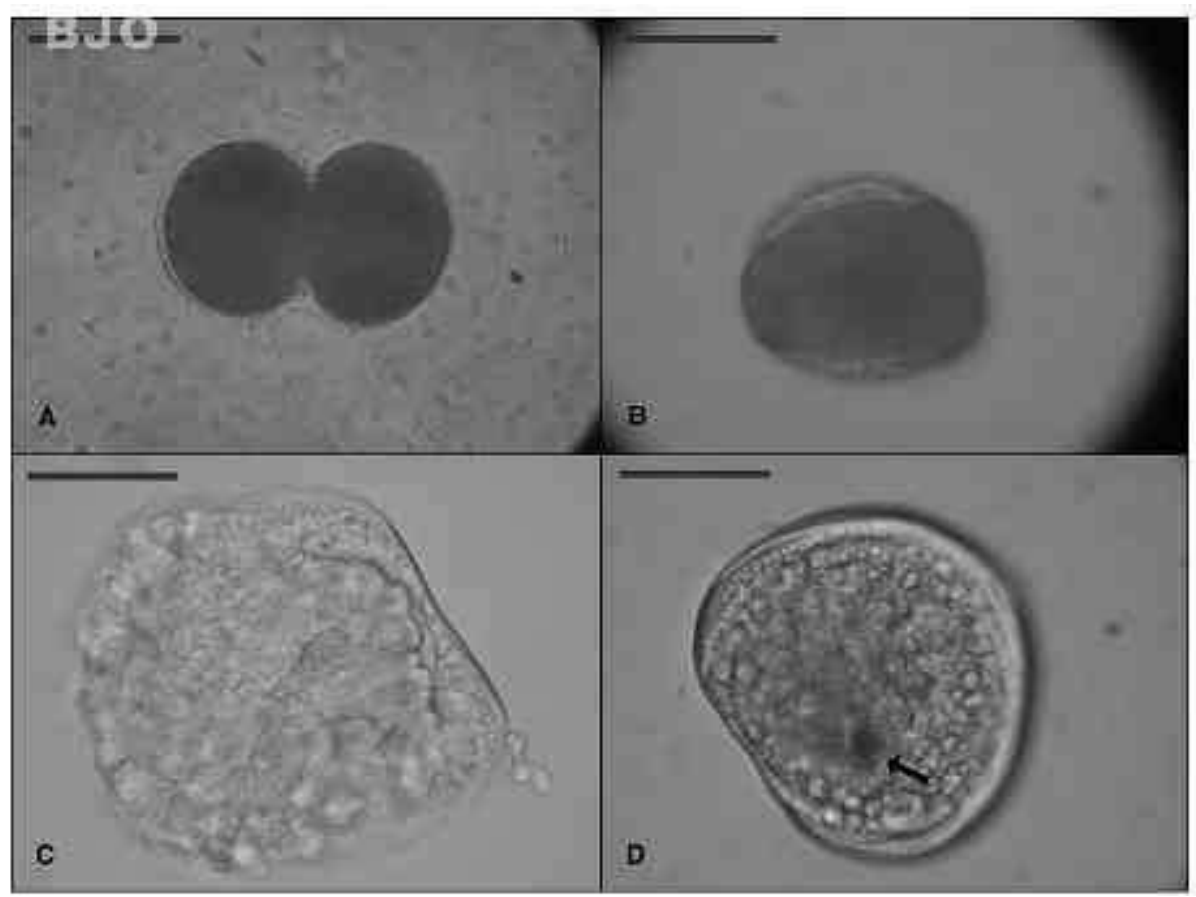

Fig. 4. Early life stages of Tridacna crocea. A: First egg cleavage ( $2 \mathrm{~h}$ post-fertilization), scale bar $50 \mu \mathrm{m}$. B:Trochophore stage, initial morphing of calcareous shells (15h p.f.), scale bar $70 \mu \mathrm{m}$. C: Early veliger stage with digestive tract formed (31h p.f.), scale bar $60 \mu \mathrm{m}$. D: Late veliger with zooxanthellae acquired (arrow) and well-defined shells (100h p.f.), scale bar $70 \mu \mathrm{m}$.

the aperture and the gonads, save a thick muscle layer. In mantle cavity injections it is common to pierce the heart. Spawned eggs were viable and fertility rate was ca. $95 \%$, very much above the minimal $80 \%$ recommended for culturing (ELLIS, 1998).

Mean length of embryos of Tridacna crocea was very similar to those reported for giant clams in the wild (mean ca. $92 \mu \mathrm{m}$; JAMESON, 1976), suggesting oocytes were ripe upon spawning. Twenty hours post-fertilization, free-swimming and nonfeeding trochophores (FITT et al., 1984) had already grown $12 \%$. That occurred because of morphological changes, such as the beginning of gastrulation and growing of cilia and apical tuft, with a slight elongation of the body. These changes naturally resulted in high mortality (Fig. 1) due to poorly formed organs in unviable larvae. When morphing into veligers, larvae experienced increased length mainly because of the genesis of calcareous shells, whereas visceral mass grew little, rearranging itself and forming the digestive tract (Fig. 4). Feeding began and larvae continued to grow, but at lower rates (see also GWYTHER; MUNRO, 1981; RICO-VILLA et al., 2009). Despite veligers being provided with microalgae, the growth rate did not increase until the acquisition of zooxanthellae, when larvae apparently grew daily a mean $25 \%$ faster than when symbionts were not available (Fig. 2). Previous work (FITT et al., 1984) had stressed that the symbiotic relationship between $T$. crocea and $S$. microadriaticum was not established until after metamorphosis, when the dinoflagellates migrate from the digestive tract to the haemal sinuses of the hypertrophied siphon (TRENCH et al., 1981). However, more recent findings have determined that zooxanthellae must be seeded into the clams as early as day four, otherwise mortality can be considerably higher (ELLIS, 1998; FATHERREE, 2006; KNOP, 2009). Fitt et al. (1984) did not perform any quantitative study so as to determine if at any given point the zooxanthellae were providing the larvae with any kind of metabolite. Based on histological observations, different authors affirm that photosymbiosis is established around day eighteen, shortly before metamorphosis (HIROSE et al., 2006). However, present findings suggest symbionts may be active as early as day four, long before metamorphosis. Between 24 and $36 \mathrm{~h}$ after zooxanthellae addition, growth rates increased where they had previously been declining (Fig. 3). Fitt et al. (1986) concluded that larval growth is enhanced after live zooxanthellae are ingested by Tridacna gigas and Hippopus hippopus, and hypothesized that 
photosynthetically fixed carbon might be translocated from $S$. microadriaticum to the veligers. In addition, studies on the coral-zooxanthellae symbiosis also point out that growth and settlement are benefitted by the presence of zooxanthellae, especially before metamorphosis (GAITHER; ROWAN, 2010; SCHWARZ et al., 1999).

Of all the main five species of the genus Tridacna ( $T$. crocea, $T$. maxima, $T$. squamosa, $T$. derasa and $T$. gigas), the boring giant clam Tridacna crocea presents the slowest growth and the highest mortality rates (HART et al., 1998). Tridacna crocea is also the giant clam species that takes longest to metamorphose (FITT et al., 1986), which makes it the hardest to breed in captivity. The first measurements of clam larvae (JAMESON, 1976) used only 5 individuals and irregular measuring intervals and calculated that during the first ten days of life, $T$. crocea had a mean growth of $8 \mu \mathrm{m}$ day-1. Other, earlier literature recorded that $T$. crocea grew at a rate of ca. $1.4 \mathrm{~mm}$ month $^{-1}$ or an average $46 \mu \mathrm{m}_{\text {day }}{ }^{-1}$ during the first 17 months, when measurements were taken every 5 months (HART et al., 1998). The present study shows that early growth may be more than three times slower during the first week of life than the 17-month mean reported by Hart et al., (1998) and twice as fast as that presented by Jameson (1976). Studies focusing on zooxanthellae activity in clams have estimated that when lighting and nutrient concentrations are appropriate $T$. crocea can grow from 10 to $50 \mu \mathrm{m}$ day $^{-1}$ (KLUMPP; GRIFFITHS, 1994). However, none of the articles cited above measured the larvae daily, they only calculated means and estimates based on monthly growth and a few measurements. Further, the larval growth presented here was measured before and after the larvae had the benefit of acquiring symbionts. The daily measurement of larvae may greatly benefit and determine the eventual success or failure of attempts to rear the larvae of tridacnid clams.

\section{ACKNOWLEDGEMENTS}

We would like to sincerely thank Dr. William Fitt of the University of Athens in Georgia, U.S., who contributed with enormous informational input during the process of conceiving the first culture of tridacnids in Brazil. Our gratitude must also be extended to Arthur Güth for statistical assistance, Dr. Sergio Mies of the Faculty of Medicine of the University of São Paulo for assisting with antibiotics, Rodrigo Carvalho of UFRN for help with aquaculture issues and Ricardo Rio of Fishland for providing adult specimens.

\section{REFERENCES}

BECKVAR, N. Cultivation, spawning, and growth of the giant clams Tridacna gigas, $T$. derasa and T. squamosa in Palau, Caroline Islands. Aquaculture, v. 24, p. 21-30, 1981.

BRALEY, R. D. Serotonin-induced spawning in giant clams (Bivalvia: Tridacnidae). Aquaculture, v. 47, p. 321325, 1985.

CULKIN, F.; COX, R. A. Sodium, potassium, magnesium, calcium and strontium in sea water. Deep-Sea Res., v. 13, p. 789-804, 1966.

DELBEEK, J. C.; SPRUNG J. The Reef Aquarium. v. 2. Coconut Grove, Fl.: Ricordea Publishing, 1997. 546 p.

ELLIS, S. Spawning and early larval rearing of giant clams (Bivalvia: Tridacnidae). Center for Tropical and Subtropical Aquaculture. Publication CTSA \#130, 55 p., 1998.

ELLIS, S. Nursery and grow-out techniques for giant clams (Bivalvia: Tridacnidae). Center for Tropical and Subtropical Aquaculture. Publication CTSA \# 143, 99 p., 2000.

FATHERREE, J. Giant Clams in the Sea and the Aquarium. Tampa, Fl.: Liquid Media Publications, 2006. $227 \mathrm{p}$.

FITT, W. K.; TRENCH, R. K. Spawning, development, and acquisition of zooxanthellae by Tridacna squamosa (Mollusca: Bivalvia). Biol. Bull., v. 161, p. 213-235, 1981.

FITT, W. K.; FISHER, C. R.; TRENCH, R. K. Larval biology of tridacnid clams. Aquaculture, v. 39, p. 189195, 1984.

FITT, W. K.; FISHER, C. R.; TRENCH, R. K. Contribution of the symbiotic dinoflagellate Symbiodinium microadriaticum to the nutrition, growth and survival of larval and juvenile tridacnid clams. Aquaculture, v. 55, p. 5-22, 1986.

FITT, W. K.; HESLINGA, G. A.; WATSON, T.C. Use of antibiotics in mariculture of giant clams (f. Tridacnidae). Aquaculture, v. 104, p. 1-10, 1992.

GABBOTT, P. A. Storage cycles in marine bivalve molluscs: a hypothesis concerning the relationship between glycogen metabolism and gametogenesis. In: EUROPEAN MARINE BIOLOGY SYMPOSIUM, 9, 1975. BARNES, H. (Ed.). Proceedings... Aberdeen: Aberdeen University Press, 1975. p. 191-211.

GAITHER, M. R.; ROWAN, R. Zooxanthellar symbiosis in planula larvae of the coral Pocillopora damicornis. J. expl mar. Biol. Ecol.,v. 386, p. 45-53, 2010.

GIBBONS, M. C.; CASTAGNA, M. Serotonin as an inducer of spawning in six bivalve species. Aquaculture, v. 40, p. $189-191,1984$.

GWYTHER, J.; MUNRO, J. L. Spawning induction and rearing of larvae of tridacnid clams (Bivalvia: Tridacnidae). Aquaculture, v. 24, p. 197-217, 1981.

HART, A. M.; BELl, J. D.; FOYLE, T. P. Growth and survival of the giant clams, Tridacna derasa, T. maxima and $T$. crocea, at village farms in the Solomon Islands. Aquaculture, v. 165, p. 203-220, 1998.

HESLINGA, G. A.; PERRON, F. E.; ORAK, O. Mass culture of giant clams (f. Tridacnidae) in Palau. Aquaculture, v. 39, p. 197-215, 1984. 
HIROSE, E.; IWAI, K.; MARUYAMA, T. Establishment of the photosymbiosis in the early ontogeny of three giant clams. Mar. Biol., v. 148, p. 551-558, 2006.

ISHIKURA, M.; ADACHI, K.; MARUYAMA, T. Zooxanthellae release glucose in the tissue of a giant clam, Tridacna crocea. Mar. Biol., v. 133, p. 665-673, 1999

JAMESON, S. C. Early life history of the giant clams Tridacna crocea Lamarck, Tridacna maxima (Röding) and Hippopus hippopus (Linnaeus). Pacif. Sci., v. 30, p. 219-233, 1976.

LEUNG, P.; SHANG, Y. C.; WANITPRAPHA, K.; TIAN, $X$. Production economics of giant clams (Tridacna species) culture system in the U.S.-affiliated Pacific islands. Center for Tropical and Subtropical Aquaculture. Publication CTSA \# 114. 40 p., 1993.

KLUMPP, D. W.; GRIFFITHS, C. L. Contributions of phototrophic and heterotrophic nutrition to the metabolic and growth requirements of four species of giant clam (Tridacnidae). Mar. Ecol. Progr. Ser., v. 115, p. 103 $115,1994$.

KNOP, D. Giant Clams: A Comprehensive Guide to the Identification and Care of Tridacnid Clams. Ettlingen: Dähne Verlag, 1996. 255 p.

KNOP, D. Riesenmuscheln: Arten und Pflege im Aquarium. Ettlingen: Dähne Verlag, 2009. 220 p.

MIES, M.; BRAGA, F.; SCOZZAFAVE, M. S.; SUMIDA, P. Y. G. ; LEMOS, D. Successful spawning and a possible solution for broodstock mortality in giant clams (Tridacnidae): a neurotransmitter injection through the byssal orifice. Aquacult. Res., v.42(12). 2011.
MINGOA-LICUANAN, S. S. Induction of symbiosis in Tridacna crocea (C. Bivalvia, F. Tridacnidae) using zooxanthellae from $T$. gigas and $T$. crocea: effects on clam survival and growth. Science Diliman, v. 2, n. 12, p. 28-32, 2000.

NASH, W. J.; PEARSON, R. G. ; WESTMORE, S. P. A histological study of reproduction in the giant clam Tridacna gigas in the north-central Great Barrier Reef. Canberra: ACIAR Monograph Series n. 9, 1988. p. 89-94.

NORTON, J. H.; JONES, G. The giant clam: an anatomical and histological atlas. Canberra: ACIAR Monograph Series n. 14, 1992. p 1-142 p.

RICO-VILLA, B.; POUVREAU, S.; ROBERT, R. Influence of food density and temperature on ingestion, growth and settlement of Pacific oyster larvae, Crassostrea gigas. Aquaculture, v. 287, p. 395-401, 2009.

SCHWARZ, J. A.; KRUPP, D. A.; WEIS, V. M. Late larval development and onset of symbiosis in the scleractinian coral Fungia scutaria. Biol. Bull., v. 196, p. 70-79, 1999.

TRENCH, R. K.; WETHEY, D. S.; PORTER, J. W. Observations on the symbiosis with zooxanthellae among the Tridacnidae (Mollusca, Bivalvia). Biol. Bull., v. 161 , p. $180-198,1981$.

YONGE, C. M. Mode of life, feeding, digestion and symbiosis with zooxanthellae in the Tridacnidae. Sci. Rept Great Barrier Reef Expedition, v. 1, p. 283-321, 1936.

(Manuscript received 02 February 2011; revised 05 May 2011; accepted 14 September 2011) 